\title{
Membrane Cofactor Protein of Complement Is Present on Human Fibroblast, Epithelial, and Endothelial Cells
}

\author{
Terry McNearney, Laura Ballard, Tsukasa Seya, and John P. Atkinson \\ Howard Hughes Medical Institute Laboratories and Division of Rheumatology, Department of Medicine, \\ Washington University School of Medicine, St. Louis, Missouri 63110
}

\begin{abstract}
Membrane cofactor protein (MCP) of the complement system is a iC3/C3b binding molecule with cofactor activity that has been identified on all human peripheral blood cells except erythrocytes. Human mononuclear and platelet MCP is dimeric with molecular weights of 68,000 and 63,000 and is expressed in three phenotypic patterns. To further determine its tissue distribution, surface-labeled human fibroblast, epithelial, and endothelial cells and cell lines were assessed for the presence of MCP by iC3 affinity chromatography and by immunoprecipitation with a monospecific anti-MCP rabbit polyclonal antibody. All sources of adult and fetal fibroblast and epithelial cells and cell lines examined and umbilical vein endothelial cells expressed MCP. The molecular weight and phenotypic patterns of MCP were similar to those of peripheral blood cells. MCP was synthesized by fibroblast and epithelial cell lines. Solubilized extracts of these cell lines expressed factor I-dependent cofactor activity for the first cleavage of $\mathrm{iC} 3 / \mathrm{C} 3 \mathrm{~b}$ which was abrogated by removal of MCP. Expression of MCP was modulated by SV40 transformation of two fetal fibroblast lines. There was a 5- to 10-fold increase in expression of MCP and a preferential expression of the lower species such that the phenotypic designation was changed. The wide tissue distribution and activity profile of MCP suggest that it is likely to play an important role in the regulation of the complement cascade.
\end{abstract}

\section{Introduction}

Membrane cofactor protein (MCP'; formerly named gp45-70) of complement binds iC $3 / \mathrm{C} 3 \mathrm{~b}$ and, less avidly, $\mathrm{iC} 4 / \mathrm{C} 4 \mathrm{~b}(1,2)$. It possesses factor I-dependent cofactor activity (1-3) for these components and thereby has the potential to inhibit their function in the complement system. MCP is expressed on peripheral blood cells, including granulocytes, $T$ and $B$ lymphocytes, monocytes, and platelets, but not erythrocytes $(1,3,4)$. In all peripheral blood cells except granulocytes, MCP is a dimeric protein with molecular weights of the two species of 68,000 and 63,000 (SDS-PAGE, reducing conditions) $(1,3$, 4-6). All individuals express both species but in a trimodal

Address reprint request to Dr. Atkinson, Division of Rheumatology, 4566 Scott, Box 8045, St. Louis, MO 63110.

Received for publication 30 November 1988 and in revised form 8 March 1989.

1. Abbreviations used in this paper: DAF, decay-accelerating factor; MCP, membrane cofactor protein.

J. Clin. Invest.

(C) The American Society for Clinical Investigation, Inc.

0021-9738/89/08/0538/08 $\$ 2.00$

Volume 84, August 1989, 538-545 distribution in which the quantity of each species expressed is genetically regulated (5). Two codominantly inherited allelic variants appear to account for the three phenotypic patterns, predominant upper band expression (66\% of the population), approximately equal (28\%) and lower band predominant $(6 \%)$ (5). MCP has been purified (2) and a monospecific polyclonal antibody has been raised $(4,5)$. Recently, the derived amino acid sequence of MCP has been determined from a cDNA clone (7). The most remarkable feature, beginning at its amino terminus, is the presence of four contiguous $\sim 60$ amino acid repeating units that match the consensus sequence found in a multigene family of complement regulatory proteins (reviewed in references 8-10). The remainder of the molecule consists of a region rich in serine and threonine (probable site of heavy O-linked glycosylation), a transmembrane hydrophobic region, and a cytoplasmic tail. The MCP structural gene was localized to human chromosome band 1q32 (7), which contains other members of the multigene family of complement regulatory and receptor proteins $(11,12)$. Utilizing pulse field gel electrophoresis the MCP structural gene has been more precisely mapped. It is located within $100 \mathrm{~kb}$ of the $3^{\prime}$ end of the CR1 gene and the order of the genes on an $\sim 800-k b$ stretch of DNA at the RCA cluster is MCP-CR1-CR2-DAFC4bp (13).

Decay accelerating activity and cofactor activity are two important mechanisms that down-regulate the complement cascade at the critical step of $\mathrm{C} 3$ activation (reviewed in references 14 and 15). Among complement receptors and regulatory proteins that interact with $\mathrm{C} 3 \mathrm{~b} / \mathrm{C} 4 \mathrm{~b}$, only decay-accelerating factor (DAF) has been shown to have a wide tissue distribution, including most peripheral blood cells $(16,17)$, endothelial (18), glandular, and epithelial cells (19). DAF possesses decay accelerating activity but no cofactor activity. In contrast, purified MCP or MCP in detergent solubilized cell extracts has the opposite activity profile of DAF, possessing cofactor but no decay-accelerating activity $(2,3)$. Based on its overall similarity to other regulators of complement activation, especially DAF, and its cofactor activity, we have hypothesized that its function is to act as cell-bound cofactor protein but this point has not yet been confirmed with intact cells. Since these two regulatory activities are important mechanisms for complement regulation, both in the fluid phase and on cell surfaces $(14,15)$, we analyzed human fibroblast, epithelial, and endothelial cells for the presence of MCP. This report describes the wide tissue of MCP and the modulation of its expression by viral transformation.

\section{Methods}

Cells. Human peripheral blood mononuclear cells were purified by gradient density centrifugation (1).

The following human fibroblast cell lines were obtained from the National Institute of General Medical Sciences Human Genetic Mutant Cell Repository, Camden, NJ: AG2603, an adult lung fibroblast 
cell line; AG2602, an adult skin fibroblast cell line from the same donor as AG2603; GM2987, an adult skin fibroblast cell line; IMR90, a human fetal lung fibroblast cell line (16 wk of gestation); AG3204, a precrisis SV40-infected IMR90 cell line, expressing the T antigen on $10 \%$ of the cells; AG2804B, a postcrisis SV40-transformed IMR90 cell line, derived from the AG3204 cell line; AG6814D, a human fetal lung fibroblast cell line ( 12 wk of gestation and formerly designated WI38); AG7217, a postcrisis SV40-transformed AG6814D cell line; GM0637B, a postcrisis-SV40 transformed daughter of GM0037C which was derived from adult skin. All postcrisis cell lines expressed $100 \%$ large $\mathrm{T}$ antigen and $1-5 \%$ of cells also expressed the $\mathrm{V}$ antigen. The postcrisis cell lines expressed the same HLA type and G6PD isoenzyme pattern as the parent cell line (personal communication, Dr. Lorraine Toji, National Institute of General Medical Sciences Human Genetic Mutant Cell Repository).

HEp-2, a cell line established from a carcinoma of the larynx, and HeLa, a cell line derived from a carcinoma of the cervix, were obtained from American Type Culture Collection, Rockville, MD. Keratinocytes, derived from normal adult human skin, were isolated and grown in primary culture (generous gift of Alice Pentland, Division of Dermatology, Washington University School of Medicine) (20). Endothelial cells were obtained from a primary culture of human umbilical vein and purified and cultured according to previously published methods (generous gift of Pamela Manning and Jitka Olander, Monsanto Laboratories, St. Louis, MO) (21).

The above cell populations were grown in monolayers in T-flasks in media containing $\alpha$-MEM with $10 \%$ fetal calf serum, $30 \mathrm{mM}$ Hepes buffer, pH 7.3, and fungizone, penicillin, and streptomycin (all provided by the Washington University Tissue Culture Center). The cells were treated with $25 \mathrm{mM}$ trypsin/5 mM EDTA to disrupt the monolayers. Cell suspensions were split 1:3 or 1:4 to increase cell members for experimental conditions (as per supplier's recommendations for cell passage). On day 3 or 4 postpassage (to allow for confluency and normalization of cell membrane proteins), the cells to be used for surface labeling were harvested by scraping or trypsin treatment. The fibroblast cell lines were used before they had undergone 20 passes. For some experiments, HeLa cells were grown in suspension.

Surface labeling. The cells were harvested and washed three times with PBS (150 mM NaCl, $10 \mathrm{mM} \mathrm{K}_{2} \mathrm{HPO}_{4}, 1.5 \mathrm{mM} \mathrm{NaH}_{2} \mathrm{PO}_{4}, \mathrm{pH}$ 7.4). The cells were resuspended in $4 \mathrm{ml} P B S$ and surface-labeled with ${ }^{125}$ I via a previously described lactoperoxidase method $(21,22)$. The cells were solubilized at a concentration of $1 \times 10^{7}$ cells $/ \mathrm{ml}$ in PBS with $1 \%$ NP-40, $2 \mathrm{mM}$ phenylmethylsulfonyl fluoride, $3 \mathrm{mM}$ ethylenediaminetetracetic acid, $1 \mu \mathrm{g} / \mathrm{ml}$ pepstatin, and $2 \mathrm{mM}$ iodoacetamide.

Biosynthetic labeling. Biosynthetic labeling was performed in 175$\mathrm{ml}$ T-flasks. The monolayers were washed three times with PBS. $4 \mathrm{ml}$ of RPMI with $10 \%$ of the normal concentration of glucose and containing $10 \%$ dialyzed fetal calf serum were added to each flask. $\left.{ }^{3} \mathrm{H}\right]$ Glucosamine $(50 \mu \mathrm{Ci}$ per flask) (New England Nuclear, Boston, MA) was added and the flasks were incubated for $18 \mathrm{~h}$ at $37^{\circ} \mathrm{C}$. At the end of incubation, the supernatant was aspirated after centrifugation at $800 \mathrm{~g}$ for $15 \mathrm{~min}$ at $4^{\circ} \mathrm{C}$. The monolayers were washed three times with PBS and then solubilized in PBS containing 1\% NP-40 and the protease inhibitors noted above.

Affinity chromatography. Solubilized cell preparations were centrifuged at $10,000 \mathrm{~g}$ for $12 \mathrm{~min}$ at $4^{\circ} \mathrm{C}$. The supernatant was then incubated at room temperature for $60 \mathrm{~min}$ with $0.3 \mathrm{ml}$ of either human IgG- (Fraction II; Miles Scientific Div., Naperville, IL) or BSA(Sigma Chemical Co., St. Louis, MO) Sepharose 4B, (Sigma Chemical Co.) (23). After centrifugation, the supernatant was diluted to $50 \mathrm{mM}$ $\mathrm{NaCl}$ in 1\% NP-40 and then rotated for $60 \mathrm{~min}$ at room temperature with iC3-Sepharose. After centrifugation, iC3-Sepharose was transferred to a Bio-Rad column (Bio-Rad Laboratories, Richmond, CA) $(11 \mathrm{ml})$ and washed with diluted PBS and 1\% NP-40 (50 times the column volume). The column was then eluted with $4 \mathrm{ml}$ of $400 \mathrm{mM}$ $\mathrm{NaCl}, 1 \% \mathrm{NP}-40$. Before being lyophilized, the eluates were dialyzed against 1 liter of water with three exchanges. The resuspended material was acetone precipitated. The pellets were then resuspended in disin- tegration buffer ( $0.25 \mathrm{M}$ Tris base, $2 \%$ SDS [wt/vol], $10 \%$ glycine, $0.002 \%$ bromophenol blue [wt/vol], $\mathrm{pH} 6.8$ ) and heated at $80^{\circ} \mathrm{C}$ for $5 \mathrm{~min}$.

Immunoprecipitation. Immunoprecipitation was performed as previously described $(4,5)$. Three preparations of MCP antibody and a matched IgG control were used. A rabbit polyclonal antibody to MCP and two Ig fractions of this antiserum were obtained by precipitation with ammonium sulfate or caprylic acid (Sigma Chemical Co.) (24). The products of immunoprecipitation using MCP antibody were identical with whole antiserum, Ig obtained by ammonium sulfate precipitation, or IgG obtained by caprylic acid precipitation. A mouse anti-human $\mathrm{C} 3 \mathrm{~b} / \mathrm{C} 4 \mathrm{~b}$ receptor (CR1) monoclonal antibody $(57 \mathrm{~F})$ was a generous gift of Eric J. Brown, Washington University School of Medicine (25). A monoclonal antibody, unknown specificity but of the same isotype as the anti-CR1 monoclonal, was used as a control. Hybridoma cell line HB-5 secreting IgG2a monoclonal anti-C3d receptor (CR2) was obtained from American Type Culture Collection. Goat anti-human factor $\mathbf{H}$ was purchased (Calbiochem-Behring Corp., La Jolla, CA). ${ }^{125} \mathrm{I}$-factor $\mathrm{H}$ was a generous gift of Timothy $\mathrm{C}$. Farries (26).

The solubilized proteins were eluted from Staphylococcus aureus protein A (Cowan I strain; Calbiochem-Behring Corp.) with disintegration buffer (see above).

Cofactor assay. Cells were scraped from the flasks, washed three times in PBS, and then solubilized in PBS, $1 \%$ NP-40, and the four protease inhibitors. Factor I was purified as described $(26,27)$. CR1 was used as a positive control and it was purified as described (25).

For the fluid-phase cofactor assays, ${ }^{125} \mathrm{I}-\mathrm{iC} 3$ was prepared using the chloramine $\mathrm{T}$ method (28). ${ }^{125} \mathrm{I}-\mathrm{iC} 3$ was incubated with solubilized preparations of cells with or without factor I for $1 \mathrm{~h}$ at $37^{\circ} \mathrm{C}$. The samples were then heated for $5 \mathrm{~min}$ at $80^{\circ} \mathrm{C}$ in disintegration buffer (see above) containing 5\% $\beta$-mercaptoethanol. A cofactor assay employing ${ }^{125} \mathrm{I}-\mathrm{C} 3 \mathrm{~b}-\mathrm{Sepharose}$ also was employed (25).

SDS-PAGE and autoradiography. SDS-PAGE was performed as previously described using either $7.5 \%, 9 \%$, or $6-18 \%$ polyacrylamide $(1,2)$. All samples were loaded onto a $3 \%$ stacking gel. Samples were reduced by treatment with $5 \% \beta$-mercaptoethanol and heating at $80^{\circ} \mathrm{C}$ for $5 \mathrm{~min}$. Quantification of the relative intensity of bands on autoradiographs was performed with a laser densitometer (Ultroscan XL; LKB Prodkter, Bromma, Sweden) (5).

General experimental design. Cells or cell lines were surface-labeled with ${ }^{125} \mathrm{I}$ or biosynthetically labeled with $\left[{ }^{3} \mathrm{H}\right]$ glucosamine, solubilized, and then subjected to iC3-affinity chromatography or immunoprecipitation. Control columns consisting of BSA-Sepharose or IgG-Sepharose were employed in all experiments using iC3-affinity columns. A nonspecific polyclonal rabbit antiserum or a monoclonal mouse antibody of unknown specificity was employed as a control in all immunoprecipitation experiments. In some cases, the eluates from the iC3affinity column were dialyzed and then immunoprecipitated. The eluates and precipitates were analyzed by SDS-PAGE (under reducing and nonreducing conditions) followed by autoradiography.

\section{Results}

Fibroblast cell lines. An adult human lung fibroblast cell line (AG2603) was analyzed for its expression of MCP. After surface labeling, MCP was identified in the solubilized cell extracts both by iC3-affinity chromatography and by immunoprecipitation (Fig. $1 A$ ). No other iC3 binding protein was identified. On AG2603 MCP is expressed as a predominantly upper-band pattern in a ratio of the upper to the lower species of 90/10 (5). This is the most common phenotypic variant, observed in $65 \%$ of individuals. Skin fibroblasts (AG2602) from the same donor as the lung fibroblasts exhibited the same molecular weight and also a predominantly upper-band pattern (Fig. $1 \mathrm{~B}$ ). Upon reduction, MCP migrated slightly more 

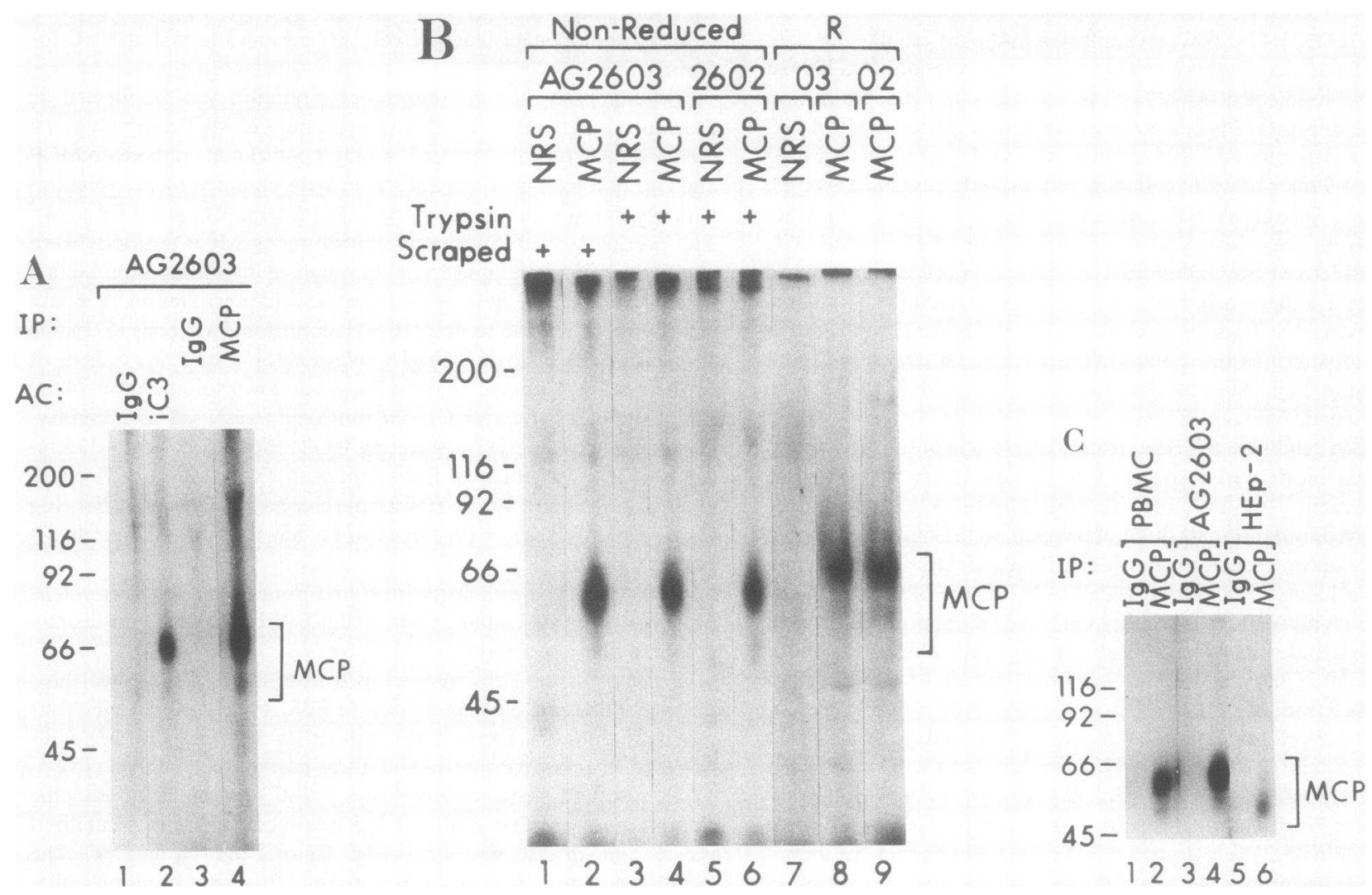

Figure 1. MCP of adult human fibroblasts. MCP was isolated by affinity chromatography $(A C)$ or immunoprecipitation (IP). (A) The AG2603 lung fibroblast cell line was harvested by trypsin/EDTA disruption of the monolayer, surface-labeled with ${ }^{125} \mathrm{I}$, and solubilized. Track 1 , human IgG-Sepharose; track 2, human iC3-Sepharose; track 3, IgG fraction of normal rabbit serum; track 4, IgG fraction of antiserum to MCP. (B) Comparison of MCP isolated from lung and skin fibroblasts of the same individual. Analysis by immunoprecipitation. NRS, normal rabbit serum; $M C P$, antiserum to MCP. AG2602, human adult skin fibroblasts (same donor as for lung fibroblasts, AG2603). $R$, reducing conditions. (C) Electrophoretic comparison of MCP of peripheral blood mononuclear cells (PBMC), fibroblasts (AG2603), and epithelial cells (HEp-2).

The solubilized cell preparations were surface-labeled and then subjected to iC3-affinity chromatography. The eluates from the affinity columns were then immunoprecipitated. The donor of PBMC is a upper-band predominant phenotype (5). Autoradiographs, SDS-PAGE (7.5\%); nonreducing conditions, except as noted.

slowly as the molecular weight of upper species was 68,000 compared with 63,000 under nonreducing conditions. A similar effect of reduction on molecular weight is observed for MCP of peripheral blood mononuclear cells and platelets $(1,2$, 4). Before surface labeling, the cells utilized for the experiments shown in Fig. $1 A$ were treated with trypsin and EDTA in order to dislodge the cells from the monolayer. MCP isolated from cells harvested by trypsin treatment or by scraping aligned (Fig. $1 B$ ).

A comparison of MCP isolated from PBMC, a fibroblast cell line and an epithelial cell line are shown in Fig. $1 C$. MCP of PBMC migrates slightly faster than MCP of AG2603, although both have the upper-band predominant phenotype. Shown for comparison is the MCP of HEp-2 which is a lowerband predominant pattern (see below and Fig. 2).

Epithelial cells and cell lines. HEp-2 (Figs. $1 C$ and $2 B$ ) and HeLa (Fig. $2 A$ ), two epithelial cell lines, were examined for expression of MCP. The upper and lower forms of MCP of HeLa cells are clearly visible in Fig. $2 A$ and have molecular weights of 63,000 and 58,000 under nonreducing conditions and of 68,000 and 63,000 under reducing conditions. These molecular weights are similar to that of MCP derived from human peripheral blood lymphocytes, fibroblasts, and HEp-2.
By densitometric scanning, the ratio of the quantity of the upper to lower species was $\sim 30 / 70$, indicating a lower-band phenotype. To assess whether untransformed epithelial cells also express MCP, low-passage keratinocytes derived from normal human skin of two donors were analyzed. MCP was expressed on these cells as an upper-band predominant pattern (not shown).

Biosynthesis of MCP by epithelial and fibroblast cells. HEp-2 cells were incubated with $\left[{ }^{3} \mathrm{H}\right]$ glucosamine, solubilized, and then subjected to iC3 affinity chromatography (Fig. $2 \mathrm{~B}$ ). Densitometric scanning of the MCP isolated from surface- and biosynthetically labeled preparations demonstrated identical molecular weights and upper to lower band ratio of 30/70. MCP was also synthesized by AG2603, a fibroblast line (not shown). The incubation media of both HEp-2 and AG2603 were assessed for MCP by immunoprecipitation and affinity chromatography, but no protein of a molecular weight similar to that of MCP was isolated (not shown).

Endothelial cells. Low-passage umbilical vein endothelial cells were analyzed for MCP. A prominent broad species with the expected molecular weight of MCP was identified by affinity chromatography and by immunoprecipitation (Fig. 3). Upon longer exposure a distinct two-band pattern was ob- 


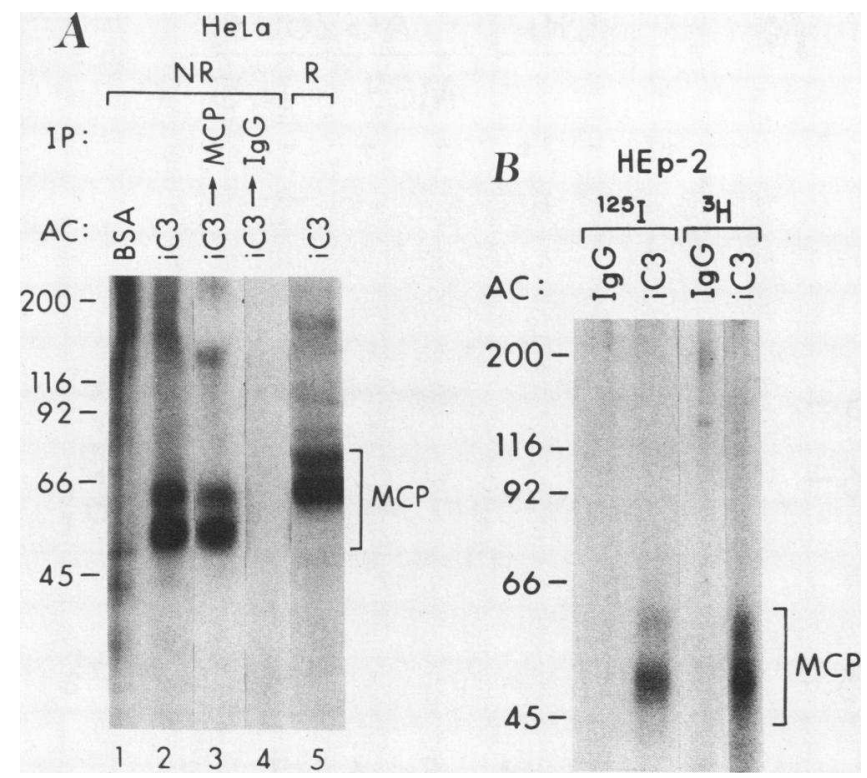

Figure 2. MCP of epithelial cells. (A) HeLa. The samples in lanes 3 and 4 were first subjected to iC3-Sepharose and then the eluate from this column was immunoprecipitated. The HeLa cells were harvested from monolayers. $N R$, nonreducing conditions; $R$, reducing conditions. (B) HEp-2 synthesizes MCP. ${ }^{125} \mathrm{I}$-surface- or $\left[{ }^{3} \mathrm{H}\right]$ glucosaminelabeled HEp-2 cells were solubilized, subjected to affinity chromatography, and compared under nonreducing conditions. Abbreviations as per Fig. 1. Autoradiographs, SDS-PAGE (7.5\%).

served and by densitometric scanning $>80 \%$ of the counts were in the upper species. No protein comparable in molecular weight to CR1 or CR2 was isolated by iC 3 affinity chromatography (Fig. 3) or by immunoprecipitation with monoclonal antibodies to CR1 or CR2 (not shown). As has been observed in the other cell types $(1,3,4,5)$, upon reduction the molecular weight of the two species of MCP was greater.

Cofactor activity of epithelial and fibroblast cell lines. Solubilized preparations of HEp-2 or AG2603, harvested from monolayers either by scraping or trypsin treatment, possessed factor I-dependent cofactor activity for iC3 (Fig. $4 A$ ). The decrease in the quantity of $\alpha$-chain paralleled the appearance of its 65,000 - and $43,000-\mathrm{mol}$ wt proteolytic fragments (29). The molecular weights of the $\alpha^{\prime} 1$ and $\alpha^{\prime} 2$ fragments generated with purified CR1 or solubilized preparations of HEp-2 were identical. If the solubilized HEp-2 or AG2603 preparations were first precleared of MCP by immunoprecipitation, cofactor activity was abolished (Fig. 4, $B$ and $C$ ). This result combined with the fact that no CR1, factor $\mathrm{H}$, or CR2 was isolated from these solubilized preparations by affinity chromatography (Figs. 1 and 2) or immunoprecipitation (not shown), indicates that MCP is responsible for this cofactor activity. Solubilized preparations from IMR90 and AG6814D, fibroblasts derived from normal fetal lung, also possessed factor I-dependent cofactor activity (not shown). In other experiments, C3b-Sepharose, rather than iC3, was employed. C3c was not released by MCP preparations but was released by CR1 (not shown).

Effect of SV40 transformation on expression of MCP by fibroblast cell lines. Human fetal lung fibroblasts (IMR90) and postcrisis SV40-infected IMR90 cells (AG2804B) were assessed for MCP (Fig. $5 A$ and Table I). IMR90, a fibroblast cell

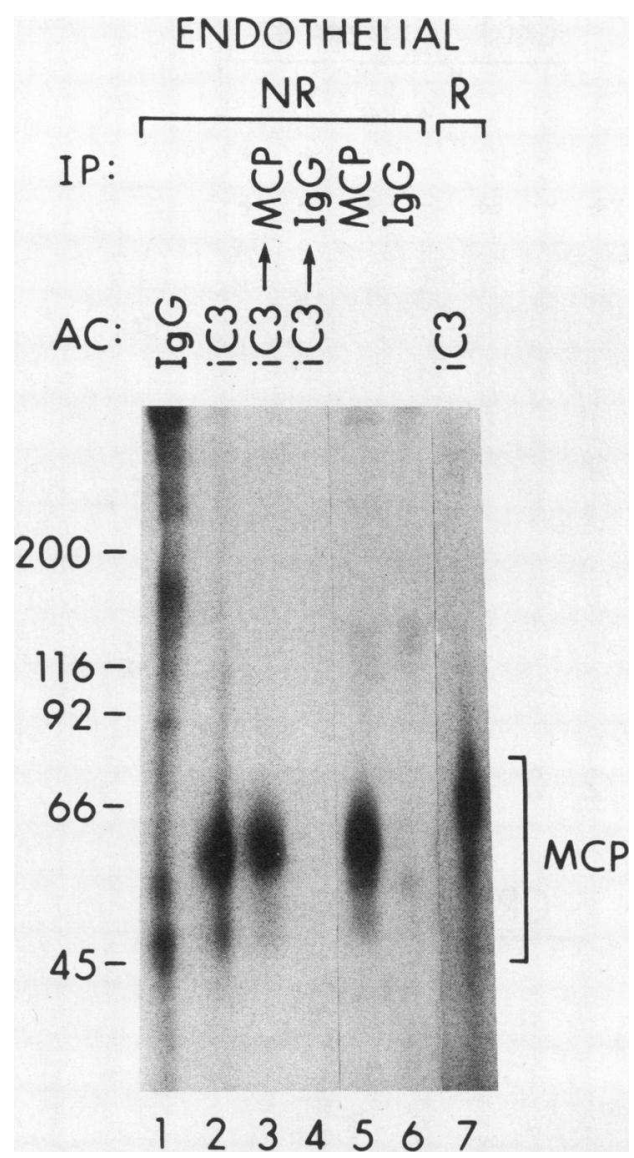

Figure 3. MCP of human umbilical vein endothelial cells. Cells were surface labeled. The samples in lanes 3 and 4 were first subjected to affinity chromatography and then the eluates from the column were immunoprecipitated. Abbreviations as per Fig. 1. Autoradiograph, SDS-PAGE (7.5\%).

line derived from normal 16-wk gestation fetal lung, expresses slightly more of the upper species $(60 / 40)$ of MCP. AG2804B expresses more of the lower species (20/80). Furthermore, based on densitometric scanning, at least fivefold more MCP was expressed by AG2804B than the parent IMR90 (equivalent cell numbers were analyzed in lanes 1 and 4). These patterns were observed in multiple experiments.

To further evaluate effects of transformation on expression, similar experiments were performed with two additional cell sources. In one instance, the parental cell line was a 12-wk-old human fetal lung fibroblast (AG6814D) and the daughter was a postcrisis SV40-transformed cell line (AG7217). The parent expressed MCP as an upper species predominant pattern (90/10) and the daughter as an approximately equal (55/45) pattern (Fig. $5 \mathrm{~B}$ ). Again, an approximately fivefold increase in expression of MCP was noted in the SV40-transformed cell line and there was preferential expression of the lower species. This increase was consistently observed in several experiments in which affinity chromatography or immunoprecipitation was utilized to isolate MCP. In addition, a cofactor assay utilizing solubilized preparations of AG6814D and AG7217 demonstrated an approximately fivefold increase in cofactor activity (not shown), comparable to the increase in the quantity of MCP. 


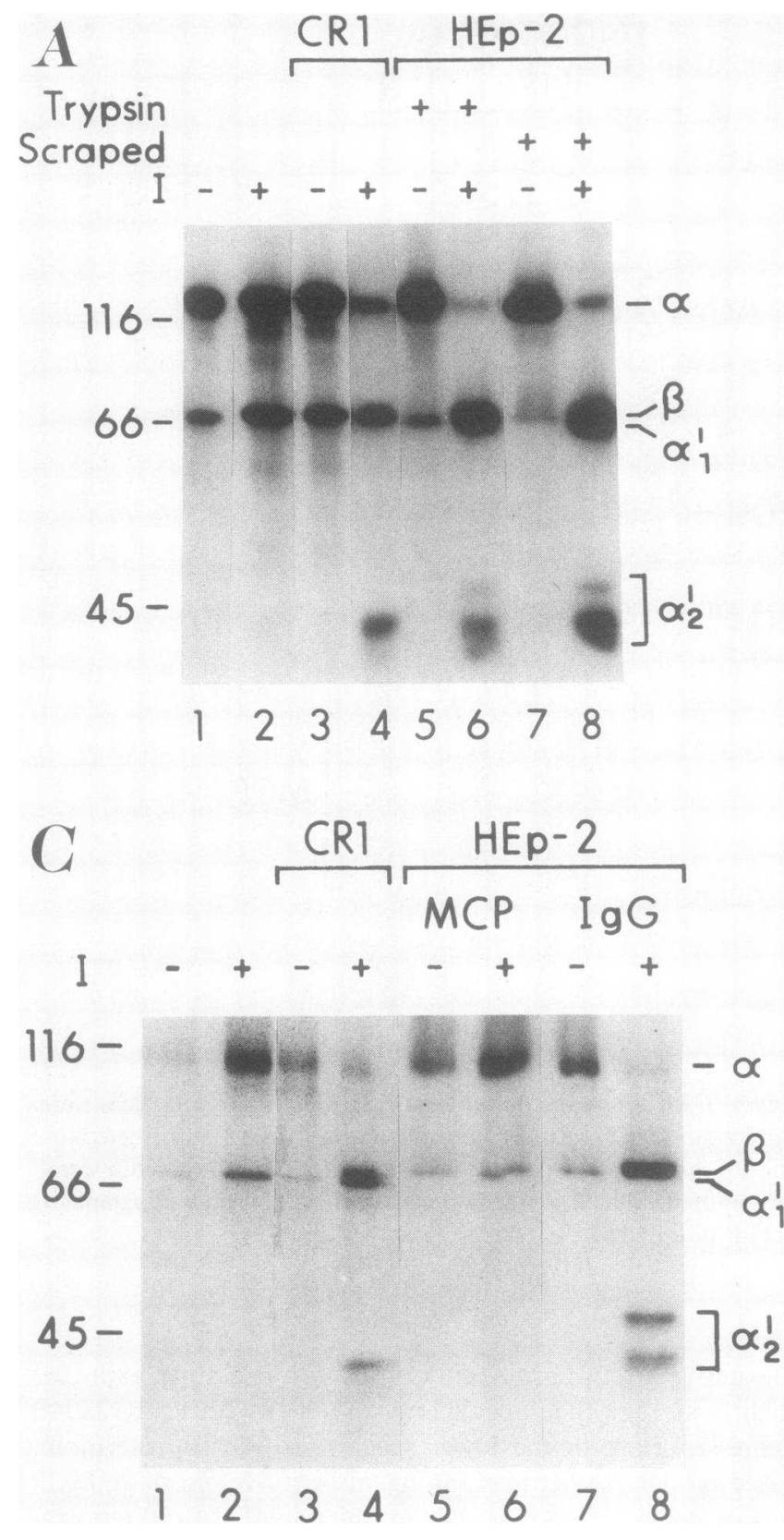

In another case, the parental cell line was a normal adult human skin (GM0037A) and the daughter was a postcrisis SV40-transformed cell line (GM0637B). SV40 transformation did not result in a change in the expression of MCP (Fig. $5 C$ ). Also, the pattern of MCP expression of the precrisis cell line (GM3204) was similar to the parent.

\section{Discussion}

Previous studies demonstrated that MCP is expressed by all human peripheral blood cell populations except erythrocytes $(1,3,4,5)$. In this report MCP was demonstrated to be present on fibroblast, epithelial, and endothelial cells. First, MCP was identified antigenically by its precipitation with a monospecific rabbit polyclonal antibody to MCP. Secondly, the same protein that was isolated by immunoprecipitation specifically bound to iC3 affinity columns. Thirdly, solubilized prepara-

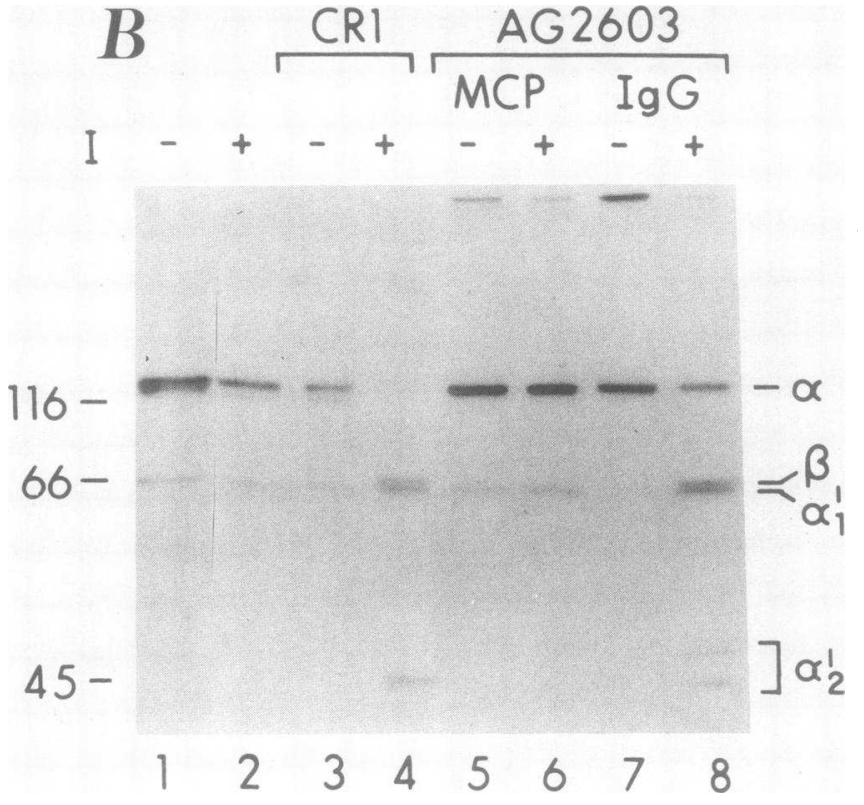

Figure 4. Epithelial and fibroblast cell lines possess cofactor activity. Solubilized extracts of HEp-2 or AG2603 were incubated with factor I and ${ }^{125} \mathrm{I}-\mathrm{iC} 3 . \mathrm{CR} 1$ is used as a positive control. $(A)$ Effect of method of harvesting cells on cofactor activity of HEp-2. (B) AG2603. (C) HEp-2. The solubilized preparations (tracks 5-8 in $B$ and $C$ ) were incubated, before assessment of cofactor activity, with IgG specific antiserum for MCP or control IgG. These antibodies were purified by caprylic acid precipitation. Autoradiographs, SDS-PAGE (9\%), reducing conditions.

tions of epithelial and fibroblast cell lines possessed factor Idependent cofactor activity for the first cleavage of $\mathrm{iC} 3 / \mathrm{C} 3 \mathrm{~b}$ and this activity was inhibited by preclearance of MCP. Fourthly, the molecular weight and phenotypic patterns, observed on autoradiographs after SDS-PAGE under reducing or nonreducing conditions, were similar to those identified for MCP of platelets (3), PBMC, and mononuclear-derived cell lines $(1,4,5)$. Fifthly, MCP was synthesized by several cell lines and its membrane location confirmed by surface labeling. These results establish that MCP of these cells and cell lines is antigenically, functionally, and structurally similar to MCP of peripheral blood cells.

Solubilized cell extracts from HEp-2 and AG2603 possessed factor I-dependent cofactor activity for iC3. Moreover, the cleavage products produced by factor I and the two extracts were similar to those observed with purified CR1 and factor I. If the solubilized preparations of these cells were first subjected 

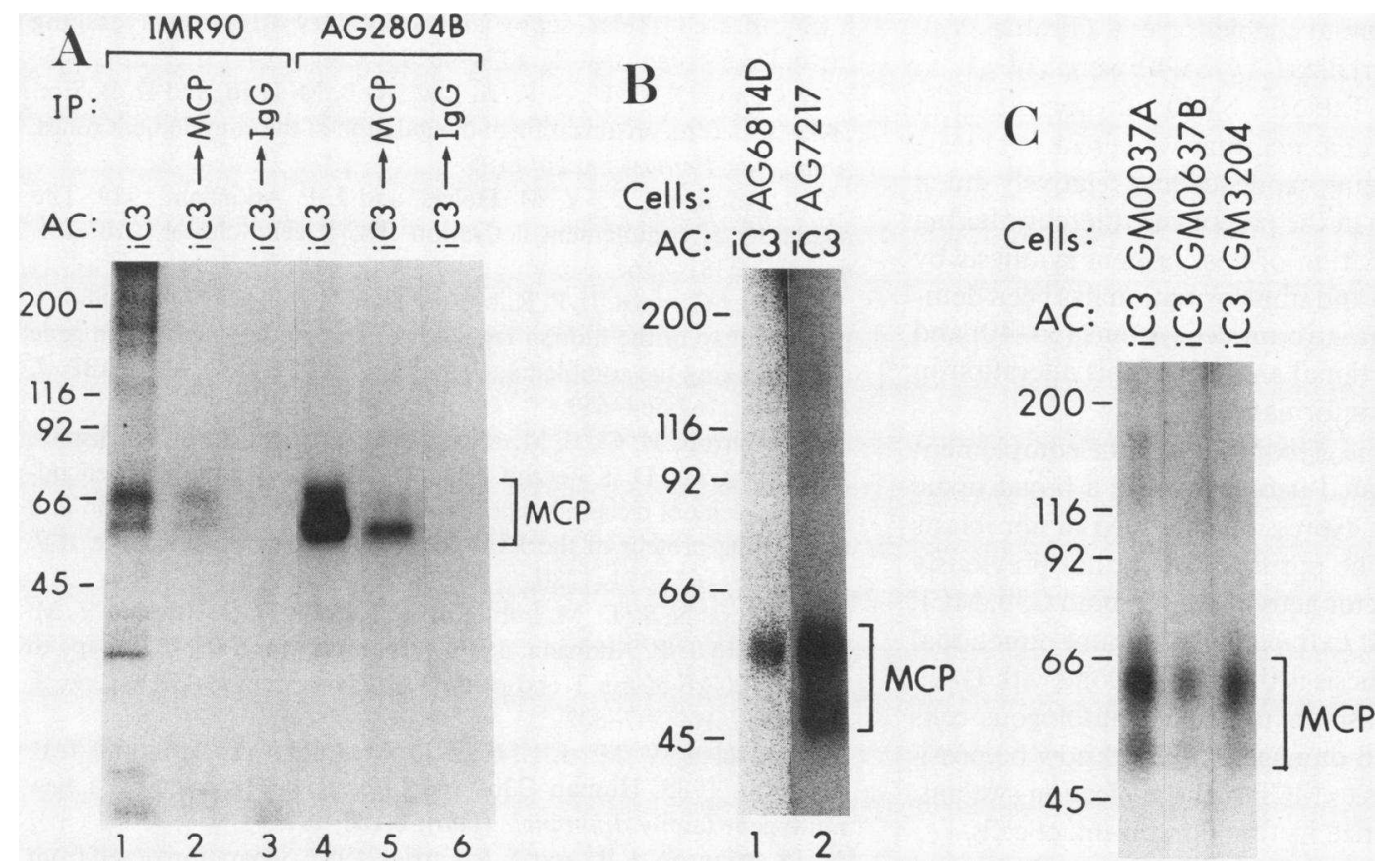

Figure 5. MCP of fetal fibroblast cell lines and their daughter SV40transformed cell lines. In these experiments, equivalent cell numbers of the fetal and its daughter cell lines were analyzed in parallel. ( $A$ ) IMR90, a 16-wk-old normal fetal lung. AG2804B, SV40transformed (postcrisis) IMR90 cell line. The samples in lanes 2 and 3 and 5 and 6 were first subjected to affinity chromatography, and then the eluates from the column were immunoprecipitated. Autoradiograph, SDS-PAGE (6-18\% gradient), reducing conditions. (B) AG6814D, a fibroblast cell line derived from a 12-wk-old fetus. AG7217, SV40-trans-

formed (postcrisis) AG6814D cell line. Lane 1 was exposed twice as long as lane 2. Autoradiograph, SDS-PAGE (7.5\%), nonreducing conditions. (C) GM0037A, adult skin fibroblast; GM0637B, SV40-transformed (postcrisis) daughter of GM0037A. AG3204, the SV40 infected (precrisis) IMR90 cell line. Autoradiograph, SDS-PAGE (7.5\%), nonreducing conditions.

to immunoprecipitation with a polyclonal antibody to $\mathrm{MCP}$, the cofactor activity was abrogated, demonstrating that MCP is the protein with cofactor activity in these preparations.

Table I. Phenotypes of MCP on Human Cells and Cell Lines

\begin{tabular}{cllc}
\hline & & \multicolumn{2}{c}{$\begin{array}{c}\text { Expression of the two } \\
\text { species of MCP }\end{array}$} \\
\cline { 3 - 4 } Cell & \multicolumn{1}{c}{ Source } & Upper/lower & Phenotype \\
\hline Fibroblasts & & & \\
AG2603 & Adult lung & $90 / 10$ & $\mathrm{U}$ \\
AG2602 & Adult skin & $90 / 10$ & $\mathrm{U}$ \\
GM2987 & Adult skin & $95 / 5$ & $\mathrm{U}$ \\
GM0037A & Adult skin & $70 / 30$ & $\mathrm{U}$ \\
GM0637B & SV40-transformed GM0037A & $70 / 30$ & $\mathrm{U}$ \\
IMR90 & Fetal lung & $60 / 40$ & $\mathrm{E}$ \\
GM3204 & SV40-infected IMR90 & $80 / 20$ & $\mathrm{U}$ \\
AG2804B & SV40-transformed IMR90 & $20 / 80$ & $\mathrm{~L}$ \\
AG6814D & Fetal lung & $90 / 10$ & $\mathrm{U}$ \\
AG7217 & SV40-transformed AG6814 & $55 / 45$ & $\mathrm{E}$ \\
Epithelial & & & \\
Keratinocyte & Normal skin 1 & $95 / 5$ & $\mathrm{U}$ \\
Keratinocyte & Normal skin 2 & $70 / 30$ & $\mathrm{U}$ \\
HEp-2 & Cancer of larynx & $20 / 80$ & $\mathrm{~L}$ \\
HeLa & Cancer of cervix & $30 / 70$ & $\mathrm{~L}$ \\
Endothelial & & & \\
Umbilical vein & Normal human & $90 / 10$ & $\mathrm{U}$ \\
\hline
\end{tabular}

Cells used in this study and their phenotype. The alphabetical designations refer to the lot number assigned to the aliquot at the time of freezing. The phenotype is defined by analyzing the quantity of the two species. Upper-band predominant, $\geq 65 \%$ expressed as the upper species; lower-band predominant, $\geq 65 \%$ of the MCP expressed as the lower species; and equal band $\leq 65 \%$ of either species is expressed. These data were obtained by densitometric scanning of the autoradiographs. Each pattern is stable in a given individual or cell line and the quantity of each species expressed is under genetic control (5).
These results are consistent with the fact that MCP was the only iC3 binding membrane protein that could be isolated from solubilized preparations of epithelial and fibroblast cell lines. The other membrane proteins with cofactor activity, CR1 and CR2, have a more limited tissue distribution and are not present on most epithelial cells and fibroblasts (reviewed in references 30-32).

DAF is present on peripheral blood cells, endothelial cells (18), glandular tissue, and epithelial cells (16). The cellular distribution of MCP also includes most peripheral blood cells, endothelial, and epithelial cells and fibroblasts (4, this report). DAF prevents the assembly and promotes the decay of the $C 3$ convertases formed on the same cell surfaces on which DAF is located (intrinsic activity) (reviewed in references 14 and 33). DAF does not, however, irreversibly inactivate the $\mathrm{C} 4 \mathrm{~b}$ or $\mathrm{C} 3 \mathrm{~b}$ and, after interaction with DAF, C3b or C4b molecules still possess hemolytic potential. In contrast, purified or solubilized cell extracts containing MCP serve as a cofactor for inactivation by factor $\mathrm{I}$, irreversibly altering $\mathrm{C} 3 \mathrm{~b}$ or $\mathrm{C} 4 \mathrm{~b}$. The resulting proteolytic cleavage product, $\mathrm{C} 3 \mathrm{bi}$ or $\mathrm{C} 4 \mathrm{bi}$, no longer may serve as a nidus for the convertase. Thus purified MCP has a related but complementary activity profile and a similar wide tissue distribution to DAF.

Predominant expression of the lower species of MCP was observed in four of the five immortalized or transformed cell lines including cells derived from two human malignancies (HEp-2 and HeLa) characterized in this study. This lower species predominant phenotypic pattern is observed in only $6 \%$ of the normal population (5). The phenotypic pattern is stable over time in a given individual and is the same on all cell types expressing MCP $(5,6)$. Although these HEp- 2 and HeLa could have both been derived from individuals expressing this uncommon phenotype, it is also possible that the expression of MCP was modulated by the malignant or immortalized state. 
Because the parent cells were available, several fibroblast cell lines that had been immortalized by SV40 were chosen to evaluate this question (see Table I). SV40 transformation of two fetal cell lines resulted in a quantitatively greater (at least fivefold) amount of MCP being expressed and relatively much more of the lower species than the parent cell, thereby altering the MCP phenotype. Regulation of host protein synthesis by SV40 virus during infection and transformation has been demonstrated in several other in vitro model systems (34-40) and further molecular and functional analysis of this alteration in MCP expression should be informative.

In summary, a membrane glycoprotein of the complement system has been demonstrated herein to have a broad tissue distribution and to have its expression modified in fibroblasts by SV40 transformation. The purified protein has previously been shown to possess cofactor activity and to bind C3b. MCP in detergent solubilized cell extracts has the same functional profile. Our working hypothesis is that MCP, along with DAF, functions in an intrinsic fashion to protect autologous cells from complement mediated damage. It should now be possible, by the use of antibodies to MCP and transfection systems, to more definitely characterize its function on intact cells.

\section{Acknowledgments}

The authors thank Donald Busiek, Stanley White, and Isabela M. Jamry in the Division of Dermatology at Washington University School of Medicine for their assistance with the fibroblast cultures. The authors thank Pat Parvin and Lorraine Whiteley for their expert secretarial assistance.

This work was supported in part by National Institutes of Health grants 5R01-AI19642, T32-AR07279, T32-AM07279, and the Eastern Missouri Chapter of the Arthritis Foundation.

\section{References}

1. Cole, J. L., G. A. Housley, Jr., T. R. Dykman, R. P. MacDermott, and J. P. Atkinson. 1985. Identification of an additional class of C3-binding membrane proteins of human peripheral blood leukocytes and cell lines. Proc. Natl. Acad. Sci. USA. 82:859-863.

2. Seya, T., J. Turner, and J. P. Atkinson. 1986. Purification and characterization of a membrane protein (gp45-70) which is a cofactor for cleavage of C3b and C4b. J. Exp. Med. 163:837-855.

3. Yu, G., V. M. Holers, T. Seya, L. Ballard, and J. P. Atkinson. 1986. Identification of a third component of complement-binding glycoprotein of human platelets. J. Clin. Invest. 78:494-501.

4. Seya, T., L. L. Ballard, N. S. Bora, V. Kumar, W. Cui, and J. P. Atkinson. 1988. Distribution of membrane cofactor protein (MCP) of complement on human peripheral blood cells. Eur. J. Immunol. 18:1289-1294.

5. Ballard, L., T. Seya, S. Teckman, D. M. Lublin, and J. P. Atkinson. 1987. A polymorphism of the complement regulatory protein MCP (Membrane Cofactor Protein or gp45-70). J. Immunol. 138:3850-3855.

6. Ballard, L. L., N. S. Bora, G. H. Yu, and J. P. Atkinson. 1988. Biochemical characterization of membrane cofactor protein of the complement system. J. Immunol. 141:3923-3929.

7. Lublin, D. M., M. K. Liszewski, T. W. Post, M. A. Arce, M. M. Le Beau, M. B. Rebentisch, R. S. Lemons, T. Seya, and J. P. Atkinson. 1988. Molecular cloning and chromosomal localization of human membrane cofactor protein (MCP): evidence for inclusion in the multi-gene family of complement-regulatory proteins. J. Exp. Med. 168:181-194.

8. Perkins, S. J., P. I. Haris, R. B. Sim, and D. Chapman. 1988. A study of human complement component Factor $\mathrm{H}$ by Fourier trans- form infrared spectroscopy and secondary structure averaging methods. Biochemistry. 27:4004-4012.

9. Campbell, R. D., S. K. A. Law, R. B. M. Reid, and R. B. Sim. 1988. Structure, organization and regulation of the complement genes. Annu. Rev. Immunol. 6:161-195.

10. Hourcade, D., V. M. Holers, and J. P. Atkinson. 1989. The regulators of complement activation (RCA) gene cluster. $A d v . I m$ munol. 45:381-416.

11. Rey-Campos, J., P. Rubinstein, and S. R. DeCordoba. 1988. A physical map of the human regulator of complement activation gene cluster linking the complement genes CR1, CR2, DAF, and C4BP. J. Exp. Med. 167:664-669.

12. Carroll, M. C., E. M. Alicot, P. J. Katzman, L. B., Klickstein, J. A. Smith, and D. T. Fearon. 1988. Organization of the genes encoding complement receptors type 1 and 2 , decay accelerating factor, and C4-binding protein in the RCA locus on human chromosome 1. J. Exp. Med. 167:1271-1280.

13. Bora, N. S., D. M. Lublin, B. V. Kumar, R. D. Hockett, V. M. Holers, and J. P. Atkinson. 1988. Structural gene for MCP maps to within $100 \mathrm{~kb}$ of the $3^{\prime}$ end of the $\mathrm{C} 3 \mathrm{~b} / \mathrm{C} 4 \mathrm{~b}$ receptor (CR1) gene. $J$. Exp. Med. 169:597-602.

14. Holers, V. M., J. L. Cole, D. M. Lublin, T. Seya, and J. P. Atkinson. 1985. Human C3b- and C4b-regulatory proteins: a new multi-gene family. Immunol. Today. 6:188-192.

15. Atkinson, J. P., and T. F. Farries. 1987. Separation of self from non-self in the complement system. Immunol. Today. 8:212-215.

16. Kinoshita, T. M., M. E. Medof, R. Silber, and V. Nussenzweig. 1985. Distribution of decay accelerating factor in the peripheral blood of normal individuals and patients with paroxysmal nocturnal hemoglobulinuria. J. Exp. Med. 162:75-92.

17. Nicholson-Weller, A., J. P. March, C. E. Rosen, D. B. Spicer, and K. F. Austen. 1985. Surface membrane expression by human blood leukocytes and platelets of decay accelerating factor, a regulatory protein of the complement system. Blood. 65:1237-1244.

18. Asch, A., T. Kinoshita, E. Jaffe, and V. Nussenzweig. 1986. Decay-accelerating factor is present on cultured human umbilical vein endothelial cells. J. Exp. Med. 163:221-226.

19. Medof, M. E., E. I. Walter, J. Rutgers, D. Knowles, and V. Nussenzweig. 1987. Identification of the complement decay-accelerating factor (DAF) on epithelium and glandular cells and in body fluids. J. Exp. Med. 165:848-864.

20. Pentland, A. P., and P. Needleman. 1986. Modulation of keratinocyte proliferation in vitro by endogenous prostaglandin synthesis. J. Clin. Invest. 77:246-251.

21. Olander, J. V., M. E. Brenner, J. C. Marasa, and J. Feder. 1985. Fibrin-enhanced endothelial cell organization. J. Cell. Physiol. 125:19.

22. Kulczycki, A., V. Krause, C. Killion, and J. P. Atkinson. 1980. Improved cell surface radioiodination of macrophages. J. Immunol. Methods. 37:133-138.

23. Dykman, T. R., J. L. Cole, K. Iida, and J. P. Atkinson. 1983. Polymorphism of human erythrocyte $\mathrm{C} 3 \mathrm{~b} / \mathrm{C} 4 \mathrm{~b}$ receptor. Proc. Natl. Acad. Sci. USA. 80:1698-1702.

24. Steinbeich, M., and R. Audran. 1969. The isolation of IgG from mammalian sera with the aid of caprylic acid. Arch. Biochem. 134:279-284.

25. Holers, V. M., T. Seya, E. J. Brown, T. T. O'Shea, and J. P. Atkinson. 1986. Structural and functional studies in the human $\mathrm{C} 3 \mathrm{~b} / \mathrm{C} 4 \mathrm{~b}$ receptor (CR1) purified by affinity chromatography using a monoclonal antibody. Complement. 3:63-78.

26. Farries, T. C., J. T. Finch, P. J. Lachmann, and R. A. Harrison. 1987. Resolution and analysis of "native" and "activated" properdin. Biochem. J. 243:507-517.

27. Seya, T., V. M. Holers, and J. P. Atkinson. 1985. Purification and functional analysis of the polymorphic variants of the $\mathrm{C} 3 \mathrm{~b} / \mathrm{C} 4 \mathrm{~b}$ receptor (CR1) and comparison with $\mathrm{H}, \mathrm{C} 4 \mathrm{~b}$-binding protein (C4bp), and decay accelerating factor (DAF). J. Immunol. 135:2661-2667. 
28. Hunter, R. 1970. Standardization of the chloramine T method of protein iodination. Proc. R. Soc. Exp. Biol. Med. 133:989-993.

29. Ross, G. D., and M. E. Medof. 1985. Membrane complement receptors specific for bound fragments of C3. Adv. Immunol. 37:217267.

30. Fearon, D. T. 1985. Human complement receptors for C3b (CR1) and C3d (CR2). J. Invest. Dermatol. 85:53s-57s.

31. Cooper, N. R., M. D. Moore, and G. R. Nemerow. 1988. Immunobiology of CR2, the B lymphocyte receptor for Epstein-Barr virus and the $\mathrm{C} 3 \mathrm{~d}$ complement fragment. Annu. Rev. Immunol. 6:85-113.

32. Mitoma, K., T. Fujita, and K. lida. 1987. Functional and antigenic properties of complement receptor type 2, CR2. J. Exp. Med. 165:1424-1429.

33. Medof, M. E. 1988. Decay accelerating factor and the defect of paroxysmal nocturnal hemoglobinuria. In Cytolytic and Complement Effectors of the Immune System. E. R. Podack, editor. CRC Press, Boca Raton, FL. 57.

34. Miranda, A. F., L. E. Babiss, and P. B. Fisher. 1983. Transfor- mation of human skeletal muscle cells by simian virus 40. Proc. Natl. Acad. Sci. USA. 80:6581-6585.

35. Steinberg, M. G., and V. Defendi. 1983. Transformation and immortalization of human keratinocytes by SV40. J. Invest. Dermatol. 81:131s-136s.

36. Tevethia, M. J., J. M. Pipas, T. Kierstead, and C. Cole. 1988. Requirements for immortalization of primary mouse embryo fibroblasts probed with mutants bearing deletions in the $3^{\prime}$ end of SV40 gene A. Virology. 162:76-89.

37. Hronis, T. S., M. L. Steinberg, V. Defendi, and T. T. Sun. 1984. Simple epithelial nature of some simian virus-40-transformed human epidermal keratinocytes. Cancer Res. 44:5797-5804.

38. Girardi, A. J., F. C. Jensen, and H. Kaprowski. 1965. SV40-induced transformation of human diploid cells crisis and recovery. $J$. Cell. Comp. Physiol. 65:69-84.

39. Rigby, P. W. J., and D. P. Lane. 1983. Structure and function of simian virus 40 large T Ag. Adv. Viral Oncol. 3:31-57.

40. Gorman, C. M., P. W. Rigby, and D. P. Lane. 1985. Negative regulation of viral enhancers in undifferentiated embryonic stem cells. Cell. 42:519-526. 